\begin{tabular}{l|c|c}
\hline ISSN: 0001-5113 & ACTA ADRIAT., & ORIGINAL SCIENTIFIC PAPER \\
AADRAY & $61(1): 39-56,2020$ & \\
\hline
\end{tabular}

\title{
Population dynamics of the Mediterranean green crab Carcinus aestuarii Nardo, 1847 (Crustacea: Portunidae) in the Gediz Delta (İzmir Bay, Eastern Aegean Sea)
}

\author{
Eyüp Mümtaz TIRAŞIN ${ }^{1 *}$, M. SALMAN², Meryem AKALIN² and Okan ÖZAYDIN² \\ ${ }^{1}$ Institute of Marine Sciences and Technology, Dokuz Eylül University, \\ Inciralti, Balcova 35340, İzmir, Turkey \\ ${ }^{2}$ Faculty of Fisheries, Ege University, Bornova 35100, İzmir, Turkey \\ *Corresponding author, e-mail: mumtaz.tirasin@deu.edu.tr
}

\begin{abstract}
A total of 6265 Mediterranean green crabs Carcinus aestuarii were sampled from the Gediz Delta in the eastern Aegean Sea (Turkey) during 24 sampling surveys with a 15-day interval from November 2014 to October 2015. The overall ratio of males to females was 1.8:1. Males were predominant in all sampling surveys, except in September 2015. The ranges of total weight $(W)$ and carapace width (CW) for all crabs were 0.19-45.74 $\mathrm{g}$ and 8-53 mm. Male crabs were, on average, larger and heavier than females. The $W-C W$ relationships were $W=0.0004 \times C W^{2.88}$ for females, and $W=0.0003 \times C W^{2.96}$ for males. The estimated von Bertalanffy growth parameters for females were: $C W_{\infty}=49 \mathrm{~mm}, K=0.82$ year $^{-1}$ and $t_{0}=-0.9$ year, and for males $C W_{\infty}=54 \mathrm{~mm}, K=0.92$ year $^{-1}$ and $t_{0}=-$ 0.96 year. The total mortality rates were 2.25 and 2.27 year ${ }^{-1}$ for females and males, respectively. The breeding season spans from mid fall to early spring peaking in winter. The recruitment of juveniles to the lagoon happens predominantly in summer. The median size at first maturity was 30.6 $\mathrm{mm}$ for females and $41.5 \mathrm{~mm}$ for males. The average potential fecundity estimate was $63565 \pm 36519$ oocytes per female crab while the average realized fecundity was $42810 \pm 33310$ eggs.
\end{abstract}

Key words: Mediterranean green crab, Carcinus aestuarii, growth, mortality, reproduction, size at first maturity

\section{INTRODUCTION}

The Mediterranean green crab Carcinus aestuarii Nardo, 1847 is a member of the Portunidae family and lives in various littoral habitats such as sandy, stony intertidal zones, brackish lagoons, seagrass meadows, estuaries and saltmarshes. It is distributed in the Atlantic Ocean around the Canary Islands, all along the coasts of the Mediterranean and the Black and the Azov Seas including the Suez Canal (FISCHER et al., 1987; ŠTEVČIĆ \& GALIL, 1993). The species can also be found along the Japanese coast as an invasive species of the Mediterranean origin (FUROTA et al., 1999). It is commonly encountered in all shores surrounding Turkey, particularly in lagoon systems and the Turkish Straits (Bosporus and Dardanelles), where considerable salinity variations occur (HOLTHUIS, 1961; KOCATAŞ \& KATAĞAN, 2003).

C. aestuarii tolerates a wide range of salinity, temperature, oxygen and substrate variations 
and, like other decapod crustaceans, constitutes an important part of the food chain in the coastal ecosystem thus plays an important role in the intermediate trophic levels (CILENTI et al., 2014). The green crab is an important food source for many commercially important fish species, particularly European eel Anguilla anguilla, European sea bass Dicentrarchus labrax and gilthead seabream Sparus aurata (MORI et al., 1990; ÖZBEK et al., 2012; GLAMUZINA et al., 2017). In addition, adult specimens in the lagoon system are preyed upon by chondrichthyan fishes, such as Rhinobatos cemiculus, and mollusks Octopus vulgaris and Sepia officinalis, while its larval stages serve as food for filter feeding aquatic birds such as flamingos (BAKLOUTI-ZOUARI, 2010).

The Mediterranean green crab is an omnivorous predator whose diet includes small bivalves with soft shells, small crustaceans, annelids as well as dead fish and other dead aquatic animals. Algae are also consumed by this crab. Its eating habits change ontogenetically and seasonally in relation with available food in its habitat (CHEN et al., 2004; BAKLOUTI-ZOUARI, 2010). In terms of human consumption, $C$. aestuarii is of a little commercial interest in most of the Mediterranean except for in some areas like Venice Lagoon in Italy, where soft shell green crabs are quite popular as a valued delicacy (MORI et al., 1990; MATOZZO et al., 2013; CILENTI et al., 2014). However, green crab is often in high demand as bait for angling and trapping (INGLE, 1997; BAKLOUTI et al., 2013a). Knowledge on the biology of green crab is still limited in the Mediterranean and in the seas surrounding Turkey. This may be due to its complex life history as it uses different habitats from the pelagic zone to the benthic zone at different ontogenetic development stages (BAKLOUTI-ZOUARI, 2010). Excluding the genetic, biochemical and toxicological studies on $C$. aestuarii (e.g. RAGIONIERI \& SCHUBART, 2013; MATOZZO et al., 2013; BAKLOUTI et al., 2013b; LEIGNEL et al., 2014; DELI et al., 2015), previous work in the Mediterranean Sea include studies on the species' population structure, morphometrics and reproductive biology in Tampan Lagoon in Camargue wetlands in southern France (CRIVELLI, 1982), in San Teodoro Lagoon on the Island of Sardinia (MORI et al.,
1990), in Varano Lagoon (CILENTI et al., 2014) and Acquatina Lagoon (LUMARE et al., 2009), both on the Adriatic coast of Italy, and in the Gulf of Gabes (BAKLOUTI et al., 2013a). Also, JOUILI et al. (2016) and GLAMUZINA et al. (2017) investigated the growth, fecundity and reproduction of the Mediterranean green crab in Elbibane Lagoon in Tunisia and in Parila Lagoon on the Adriatic coast of Croatia, respectively. In Turkey, studies on its morphometrics, length-weight relationship and reproduction biology were carried out in Ordu in the eastern Black Sea region (AYDIN, 2013), in Çakalburnu (CAN et al., 2004; CAN et al., 2007) and Homa Lagoons (KOÇAK et al., 2011; ÖZBEK et al., 2012) in İzmir Bay in the eastern Aegean Sea.

The aim of this study is to document detailed information about the reproductive biology and some aspects of the population dynamics of $C$. aestuarii inhabiting a typical estuarine habitat, Kurdeniz Lagoon in the delta of the Gediz River.

\section{MATERIALS AND METHODS}

The study site Kurdeniz Lagoon is situated in the delta of the Gediz River located in the north eastern section of İzmir Bay, close to its opening to the eastern Aegean Sea. The Gediz Delta (E $38^{\circ} 31^{\prime} \mathrm{N}$ and $026^{\circ} 53^{\prime} \mathrm{E}$ ) has been on the "List of Wetlands of International Importance" of the Ramsar Convention since 1998 [Ramsar site no. 945; https://www.ramsar.org/sites/default/files/ documents/library/ sitelist.pdf (Accessed 1 August 2019).

The delta covers an area of 14900 ha, an extensive coastal wetland with small bays, salt and freshwater marshes, large saltpans, and four highly saline lagoons including Kirdeniz Lagoon, positioned at the mouth of the Gediz River (Fig. 1).

In this study, 4058 male and 2207 female, altogether 6265 C. aestuarii specimens were collected from Kirdeniz Lagoon during 24 sampling surveys each with a 15-day interval during a one-year period from November 2014 to October 2015. The specimens were sampled from a depth range of $0.5-1.5 \mathrm{~m}$ with baited traps and fyke nets of $16 \mathrm{~mm}$ mesh size. Pieces of dead 


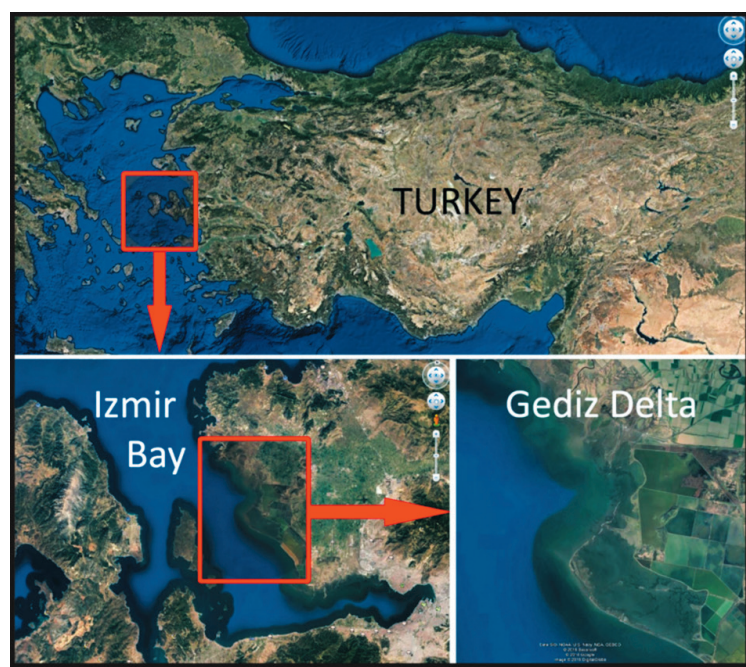

Fig. 1. Kirdeniz Lagoon (the Gediz Delta (Ramsar site no. 945), Izmir Bay, the eastern Aegean Sea, Turkey)

fish, lamb lung and chicken skin were used as bait.

The sampled crabs were preserved in the field in a $10 \%$ formalin solution and later brought to the laboratory. In the laboratory, samples were washed and the carapace length and width of each specimen were measured down to the nearest $\mathrm{mm}$ by using a digital caliber and the total body weight was recorded with a digital scale having a precision of $0.01 \mathrm{~g}$. Although carapace width $(C W)$ is more widely used to describe body size in crabs, studies reporting carapace length $(C L)$ measurements are also encountered. Therefore, in order to facilitate data comparison, a simple linear regression model (SNEDECOR \& COCHRAN, 1989) was employed to estimate the necessary coefficients to enable the conversion of these two size variables to each other. However, prior to the linear regression analysis, an analysis of covariance (SNEDECOR \& COCHRAN, 1989) was also carried out to find out whether the values of these coefficients differed according to sex.

An exact binomial test was applied to examine the difference between observed sex ratio of crabs and the expected ratio of an equal 1:1 proportion in each sampling period (SNEDECOR \& COCHRAN, 1989). In addition, a Chi-square test was employed to detect any temporal variation in sex ratios of green crabs.

The following equation was used to math- ematically define the relationship between total weight $(W)$ and $C W$ of crabs (ANDERSON \& NEUMANN, 1996):

$$
W=a \times C W^{b}
$$

In this nonlinear relationship, $a$ is a coefficient for the ratio between $W$ and $C W$, and $b$ is the exponential coefficient of raise in the body mass $(W)$ of a crab as its size $(\mathrm{CW})$ increases. The coefficients $a$ and $b$ were estimated by a linear regression analysis of natural logarithmically transformed $W$ and $C W$ data. Analysis of covariance was also carried out to determine if pairs of $a$ and $b$ values varied between females and males. Departures from isometric growth, i.e. whether the estimated $b$ is significantly different from its hypothesized value of " 3 ", were examined with a t-test (SPARRE \& VENEMA, 1998).

The growth of green crabs in the study area was described by means of the von Bertalanffy growth model (BEVERTON \& HOLT, 1957; SPARRE \& VENEMA, 1998):

$$
C W_{t}=C W_{\infty} \times\left(1-e^{-K \times\left(t-t_{0}\right)}\right)
$$

The model parameter, $C W_{\infty}$, is defined as asymptotic size, here asymptotic $C W$, and can be interpreted as the average $C W$ of very old crabs in a given population (SPARRE \& VENEMA, 1998). The $K$ and $t_{0}$ denote the curvature parameter and initial condition parameter in the model and respectively indicate the rate at which crabs grow towards their $C W_{\infty}$, and the age when crabs have zero $C W$ (BEVERTON \& HOLT, 1957; SPARRE \& VENEMA, 1998). The variables used to fit the model, $t$ and $C W_{t}$, are the age and corresponding $C W$ to that age.

The von Bertalanffy growth model was originally based on size at age data whereas ELEFAN (electronic length frequency analysis) is a computer program developed by PAULY \& DAVID (1981) for the estimation of growth parameters from size frequency data, particularly for tropical fish and other marine animals whose age data are not available. Here, the LFDA (length frequency distribution analysis) software version 5.0 (HOGGARTH et al., 2006) which incorporated the ELEFAN routine was utilized to estimate the growth parameters of female and 
male green crabs separately. Monthly $C W$ distributions, grouped into $1 \mathrm{~mm}$ class intervals for each sex, constituted the input data (Fig. 3). A comparison of growth performances between sexes was made by using the growth performance index $\left(\varphi^{\prime}\right)$ of PAULY \& MUNRO (1984):

$$
\varphi^{\prime}=\log _{10}(K)+2 \log _{10}\left(C W_{\infty}\right)
$$

The annual total mortality rate $(Z)$ for each sex was obtained by applying the method developed by BEVERTON \& HOLT (1956):

$$
\mathrm{Z}=K \times \frac{C W_{\infty}-\overline{C W}}{\overline{C W}-C W^{\prime}}
$$

This approach estimates the $Z$ from the mean size in the population and information on growth rates and size at catch. In addition to the von Bertalanffy growth parameters, $C W_{\infty}$, and $K$, $C W$, and $\overline{C W}$ in the above formula are defined as a $C W$ class which is fully exploited and mean $C W$, respectively (HOGGARTH et al., 2006). The estimator of $Z$ here is based on the assumptions that the population is in equilibrium and the recruitment is constant (SPARRE \& VENEMA, 1998). This method is also included in the LFDA software version 5.0. For each separate monthly $C W$ frequency distribution, an estimate of $Z$ was calculated by the software, the mean of these values furnished the overall annual total mortality rate $(Z)$ and the series of monthly $Z$ estimates provided the means for the calculation of a standard error of annual total mortality rate (HOGGARTH et al., 2006).

In each sampling period, a total of 250 randomly chosen specimens were dissected. Gonads were removed, examined and weighed with a precision scale of $0.01 \mathrm{~g}$. Based on the state of the gonads (i.e. visibility, size, position and color); dissected individuals were assigned to appropriate maturity stages specifically defined for $C$. aestuarii by SALMAN \& AKALIN (2019). This classification describes seven different maturity stages $(0=$ immature, $1-3=$ maturing, $4=$ mature, $5=$ ovigerous and $6=$ resting) for females and only six for males $(0=$ immature, $1-3=$ maturing, $4=$ mature and $5=$ resting). The additional stage for female maturity is defined for ovigerous females that bear a clutch of ferti- lized eggs protruding from their abdominal flaps (SALMAN \& AKALIN, 2019).

The functional relationship between crab size and state of maturity was investigated with a logistic regression analysis based on the proportion of mature crabs to the total sampled crabs during the study period. All green crabs at gonad maturity stage 4 and above were classified as mature, and those that were at preceding stages as non-mature. Then, according to this criterion, the maturation stage of each individual was converted into binary data (immature $=0$, mature $=1$ ). A logistic regression model was fit to these binomial maturity data, to determine sizes at $50 \%$ maturity for both females and males. This model is described as follows (HOSMER \& LEMESHOW, 2000):

$$
P=\frac{e^{a+b \times C W}}{1+e^{a+b \times C W}}
$$

where $P$ is the proportion of mature crabs in each size $(C W)$ interval $(\mathrm{mm})$, and $a$ and $b$ are coefficients. A generalised linear model with a binomial error structure and logit-link function was utilized to estimate the $a$ and $b$ coefficients. Then the median size at first maturity or the size $(C W)$, at which $50 \%$ of the crabs reached maturity, $C W_{50}$, also the inflection point in the logistic curve, can readily be estimated by the following formula:

$$
C W_{50}=\frac{-a}{b}
$$

The gonadosomatic index (GSI), defined as gonad weight $(G W)$ as a percentage of total body weight $(W)$, was used to describe the reproductive cycle and determine the spawning period of C. aestuarii:

$$
\mathrm{GSI}=\frac{G W}{W} \times 100
$$

Potential fecundity of female green crabs was estimated with the gravimetric method, based on the relationship between gonad weight and oocyte density in the gonad (MURUA et al., 2003). For this purpose, only female specimens at maturity stage 4 were used. In addition, the fertilized eggs attached to pleopods of ovigerous 
females at stage 5 were also counted to provide a measure of realized fecundity (MURUA et al., 2003).

Except for the logistic regression analysis based on the generalized linear model, in all other linear regression analyses, additive and normally distributed error structures were assumed. Residuals from the fitted models were checked, using various plots including normal quantile-quantile plots and Shapiro-Wilk normality tests, to verify whether the required assumptions of normality and homoscedasticity assumptions were met (SNEDECOR \& COCHRAN, 1989). All statistical tests were carried out with $R$ software version 3.3.3 (R CORE TEAM, 2017) with a significance level set at $5 \%$.

\section{RESULTS}

\section{Population sex structure}

Total of 6265 green crabs, 4058 males and 2207 females, were collected in the one-year study period. These findings corresponded to an overall ratio of males to females of 1.8:1, and this observed sex ratio was significantly different from the expected ratio of 1:1 (Binomial test). The predominance of males was seen in every sampling survey, twice a month with 15-day intervals year-round, except for in two consecutive samplings in September 2015 when the observed sex ratios were $0.94: 1$ and $0.76: 1$ in

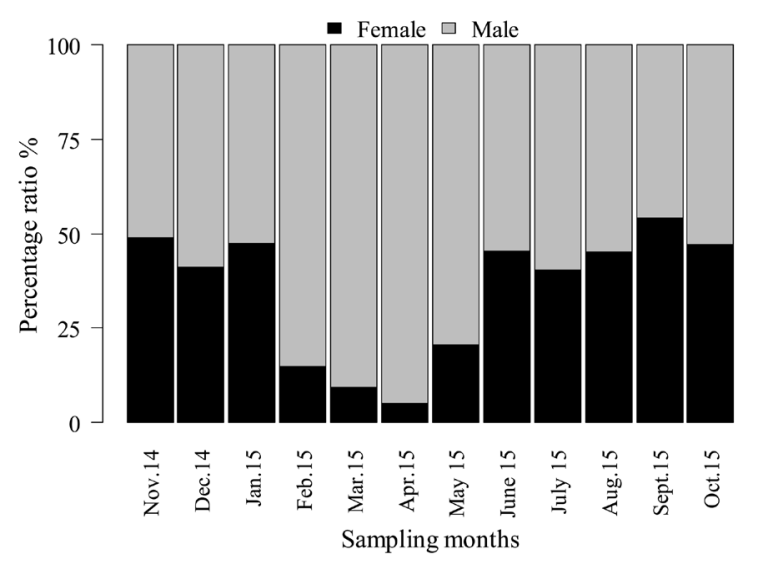

Fig. 2. Monthly variations in sex ratio of Carcinus aestuarii in Kirdeniz Lagoon in terms of percentages favor of females. Since no difference was found in sex ratios within each month (Chi-square tests), data were pooled by sampling months. The monthly variations in sex ratio in terms of observed percentages are presented in Fig. 2. The abundance of males became more marked after January 2015, and reached its peak in April 2015. Starting from June 2015, however, the proportions of females in the samples began to rise (Fig. 2).

\section{Size structure}

Both the smallest and the largest specimens measured in this study were male green crabs (Table 1). When all data were pooled together, males were, on average, bigger and heavier than females (Table 1). The observed ranges of $W$, $C W$ and $C L$ for all crabs, both sexes combined, were $0.19-45.74 \mathrm{~g}, 8-53 \mathrm{~mm}$, and $7-43 \mathrm{~mm}$, respectively (Table 1). Because the analysis of covariance results revealed that the estimated values of both intercept and slope of the linear relationship between the two size variables, $C L$ and $C W$, significantly varied according to sex, separate linear regression analyses were employed to calculate the necessary coefficients to enable the conversion of the two size variables to each other for measurements made in $\mathrm{mm}$ :

For females:

$$
\begin{array}{ll}
C L=0.2969+0.7977 \times C W & \left(N=2207, r^{2}=0.98\right), \\
C W=0.2109+1.2264 \times C L & \left(r^{2}=0.98\right),
\end{array}
$$

for males:

$$
\begin{array}{ll}
C L=0.4998+0.7868 \times C W & \left(N=4058, r^{2}=0.98\right), \\
C W=-0.0825+1.2500 \times C L & \left(r^{2}=0.98\right) .
\end{array}
$$

Monthly $C W$ distributions of green crabs grouped into $1 \mathrm{~mm}$ class intervals are presented separately for each sex in Fig. 3. A single male specimen measuring $8 \mathrm{~mm} \mathrm{CW}$ observed in August 2014 has been excluded from Fig. 3. Compared with female crabs, males, in general, had wider ranged size distributions and larger median sizes each month. Inspection of monthly size distributions also clearly showed that 
Table 1. Summary of total weight, carapace width and carapace length measurements made on the female Mediterranean green crab specimens in Kirdeniz Lagoon. $N$ and sd denote number of specimens and standard deviation, respectively

\begin{tabular}{lcccrrrc}
\hline & & \multicolumn{2}{c}{ Total weight $(\mathrm{g})$} & \multicolumn{2}{c}{ Carapace width $(\mathrm{mm})$} & \multicolumn{2}{c}{ Carapace length $(\mathrm{mm})$} \\
\multicolumn{1}{c}{ Sex } & $N$ & Mean $\pm \mathrm{sd}$ & Range & Mean $\pm \mathrm{sd}$ & Range & Mean $\pm \mathrm{sd}$ & Range \\
\hline Female & 2207 & $6.19 \pm 4.108$ & $0.35-36.72$ & $26.5 \pm 6.27$ & $10-48$ & $21.4 \pm 5.06$ & $8-39$ \\
Male & 4058 & $12.28 \pm 7.720$ & $0.19-45.74$ & $32.8 \pm 8.14$ & $8-53$ & $26.3 \pm 6.46$ & $7-43$ \\
Total & 6265 & $10.14 \pm 7.280$ & $0.19-45.74$ & $30.6 \pm 8.12$ & $8-53$ & $24.6 \pm 6.44$ & $7-43$ \\
\hline
\end{tabular}

Table 2. Estimates of total weight $(W)$ and carapace width $(C W)$ relationship parameters of the Mediterranean green crab specimens from the linear regression model: $\log (W)=\log (a)+b \log (C W) \quad N$ : number of specimens, CI: confidence interval and $r^{2}$ : determination coefficient

\begin{tabular}{lcccc}
\hline & \multicolumn{3}{c}{ Estimates } \\
\multicolumn{1}{c}{ Sex } & $N$ & $a(95 \% \mathrm{CI})$ & $b(95 \% \mathrm{CI})$ & $r^{2}$ \\
\hline Female & 2207 & $0.00042(0.00040-0.00044)$ & $2.884(2.870-2.899)$ & 0.986 \\
Male & 4058 & $0.00033(0.00032-0.00035)$ & $2.963(2.954-2.972)$ & 0.989 \\
\hline
\end{tabular}

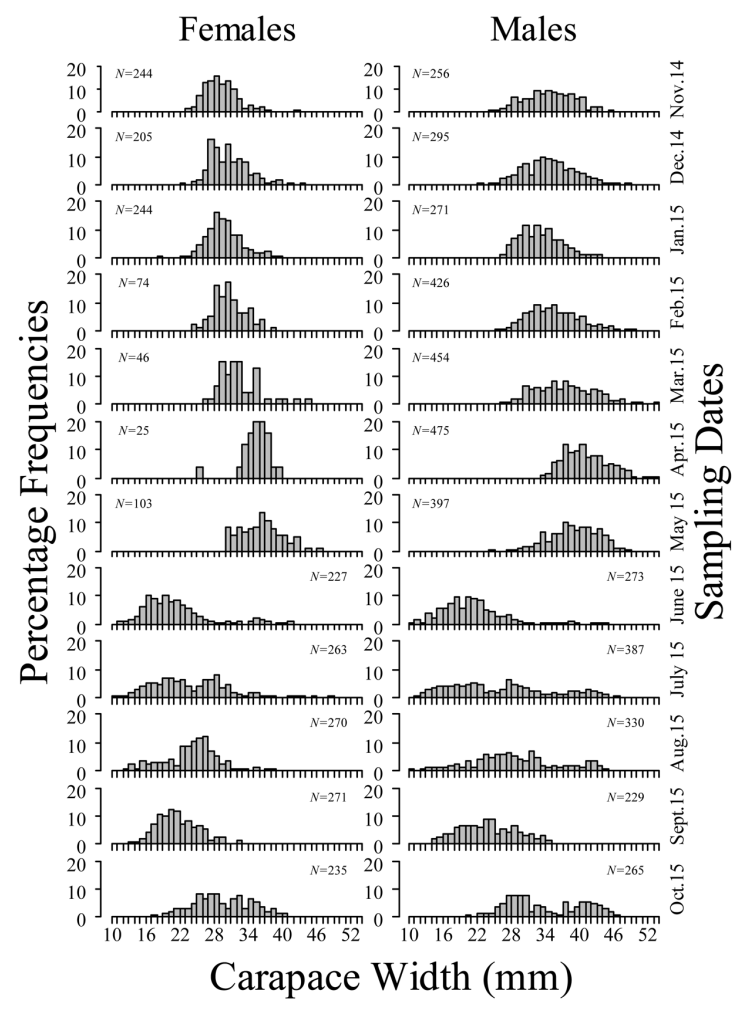

Fig. 3. Monthly carapace width distributions of Carcinus aestuarii in Kirdeniz Lagoon grouped into $1 \mathrm{~mm}$ class intervals for each sex

recruitment of green crabs in Kirdeniz Lagoon takes place in the summer months of June, July and August. The analysis of covariance showed that estimated values of $a$ and $b$ of the $W_{-}$ $C W$ relationship differed significantly between sexes. The estimated parameters for each sex are presented in Table 2. Both sexes exhibited a negative allometric growth pattern (t-test).

\section{Growth and mortality}

The von Bertalanffy growth parameters, growth performance indices and total mortality rates estimated for each sex are shown in Table 3. According to the growth parameter estimates, male crabs grew slightly faster than females and also reached a larger asymptotic size hence exhibited a greater growth performance (Table 3). The annual total mortality rates obtained separately for males and females were very close, and in fact, the difference between the two rates was not statistically significant (t-test). The values of $Z$ over 2 year $^{-1}$ corresponded to a very high annual total mortality rate that only a minuscule portion of every year class of green crabs in Kirdeniz Lagoon could be expected to survive after their second year.

\section{Gonads and maturity stages}

Size $(C W)$ ranges of all sampled green crabs according to sex and maturity stages are presented in Table 4. The minimum observed $C W$ at onset of sexual maturation (stage 1) was 15 $\mathrm{mm}$ for males and $17 \mathrm{~mm}$ for females. How- 
Table 3. The von Bertalanffy growth parameters, growth performance indices and total mortality rates estimated for each sex of the Mediterranean green crab in Kirdeniz Lagoon. N, GPI and CI denote number of specimens, growth performance index and confidence interval, respectively

\begin{tabular}{lcccccc}
\hline & \multicolumn{4}{c}{ von Bertalanffy growth parameters } & GPI & \multicolumn{2}{c}{ Total mortality rate } \\
Sex & $N$ & $C W_{\infty}(\mathrm{mm})$ & $K\left(\right.$ year $\left.^{-1}\right)$ & $t_{0}($ year $)$ & $\varphi^{\prime}$ & $Z\left(95 \%\right.$ CI) $\left(\right.$ year $\left.^{-1}\right)$ \\
\hline Female & 2207 & 49.3 & 0.81 & -0.95 & 3.29 & $2.28(1.58-2.98)$ \\
Male & 4058 & 54.0 & 0.92 & -0.86 & 3.43 & $2.26(1.59-2.93)$ \\
\hline
\end{tabular}

Table 4. Mean sizes and ranges, in terms of carapace width, of the Mediterranean green crab specimens sampled throughout the study period in Kirdeniz Lagoon according to sex and maturity stages. $N$ and sd denote number of specimens and standard deviation, respectively

\begin{tabular}{|c|r|r|r|r|r|r|}
\hline Maturity & \multicolumn{3}{|c|}{ Carapace width $(\mathrm{mm})$ (Females) } & \multicolumn{3}{c|}{ Carapace width (mm) (Males) } \\
Stages & \multicolumn{1}{|c|}{$N$} & Mean $\pm \mathrm{sd}$ & Range & $N$ & Mean \pm sd & Range \\
\hline 0 & 812 & $20.4 \pm 4.00$ & $10-30$ & 542 & $18.8 \pm 3.97$ & $8-31$ \\
\hline 1 & 208 & $26.6 \pm 3.02$ & $17-34$ & 244 & $24.0 \pm 3.40$ & $15-34$ \\
\hline 2 & 272 & $28.0 \pm 3.46$ & $17-36$ & 1056 & $31.5 \pm 4.49$ & $16-48$ \\
\hline 3 & 282 & $30.3 \pm 3.98$ & $22-43$ & 1253 & $36.4 \pm 4.39$ & $24-49$ \\
\hline 4 & 446 & $30.7 \pm 3.83$ & $22-48$ & 874 & $40.1 \pm 4.56$ & $24-53$ \\
\hline 5 & 18 & $32.6 \pm 3.91$ & $27-39$ & 89 & $36.9 \pm 6.31$ & $28-53$ \\
\hline 6 & 169 & $35.0 \pm 3.65$ & $26-46$ & - & - & - \\
\hline
\end{tabular}

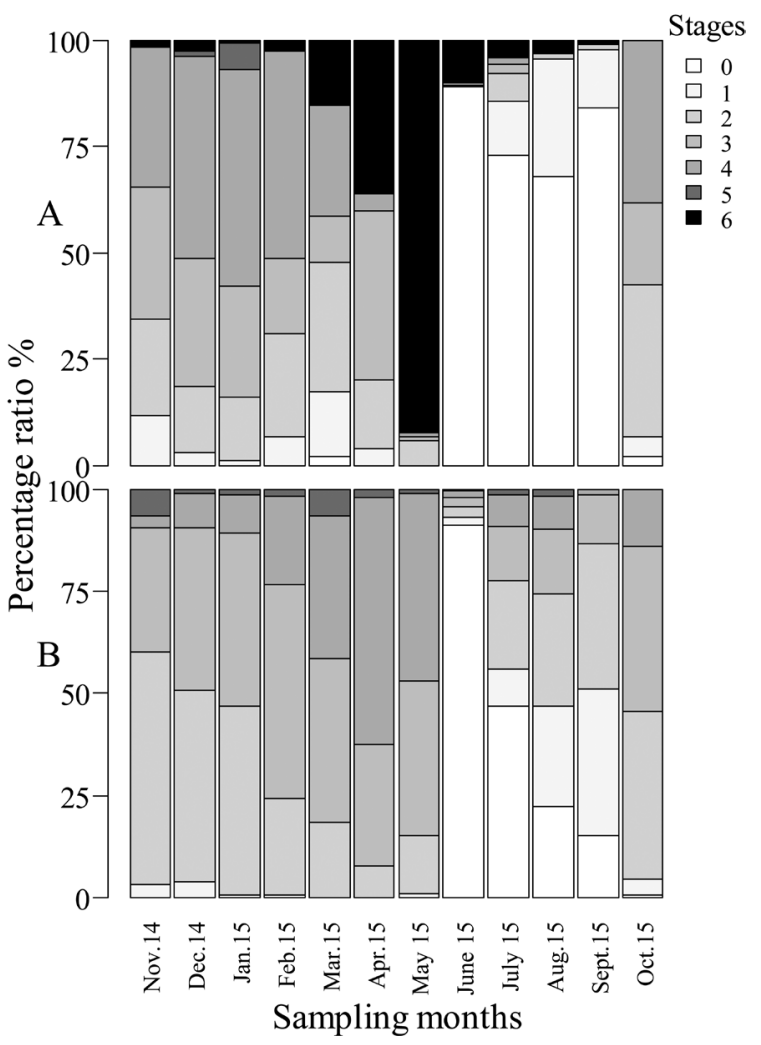

Fig. 4. Percentage distributions of the maturity stages of the female (A) and male (B) Carcinus aestuarii in each sampling month in Kirdeniz Lagoon ever, much bigger immature male and female crabs were also recorded (Table 4). The smallest mature (stage 4) female and male specimens measured had a $C W$ of 22 and $24 \mathrm{~mm}$, respectively (Table 4). The number of ovigerous females encountered was low, only 18, and their size range varied from 27 to $39 \mathrm{~mm}$ of $C W$ (Table 4).

The percentage distributions of the maturity stages of female and male green crabs in each sampling month are presented separately in Fig. 4. Mature females belonging to stage 4 were encountered almost every month, except for in August and September 2015 (Fig. 4A). They were abundant in the samples from November 2014 , in the beginning of the study, to February 2015 . The highest proportion $(51.0 \%)$ was observed in January 2015. Starting from April 2015, the presence of mature females in the samples fell and they totally disappeared in August and September 2015. In October 2015, at the end of the study period, mature females again became abundant in the samples (Fig. 4A). Ovigerous females (stage 5) were only seen in December 2014 and January 2015. Rest- 
Table 5. Means and ranges of weights of gonads of the Mediterranean green crab specimens sampled throughout the study period in Kirdeniz Lagoon according to sex and maturity stages. $N$ and sd denote number of specimens and standard deviation, respectively

\begin{tabular}{|c|r|c|c|r|c|c|}
\hline Maturity & \multicolumn{3}{|c|}{ Gonad weight (g) (Females) } & \multicolumn{3}{c|}{ Gonad weight (g) (Males) } \\
Stages & $N$ & Mean $\pm \mathrm{sd}$ & Range & $N$ & Mean $\pm \mathrm{sd}$ & Range \\
\hline 1 & 208 & $0.032 \pm 0.0271$ & $0.00-0.13$ & 244 & $0.027 \pm 0.0217$ & $0.00-0.16$ \\
\hline 2 & 272 & $0.118 \pm 0.0798$ & $0.01-0.74$ & 1056 & $0.102 \pm 0.0525$ & $0.01-0.60$ \\
\hline 3 & 282 & $0.384 \pm 0.1870$ & $0.08-1.04$ & 1253 & $0.199 \pm 0.0803$ & $0.10-0.66$ \\
\hline 4 & 446 & $0.814 \pm 0.4006$ & $0.13-3.31$ & 874 & $0.346 \pm 0.1464$ & $0.13-1.38$ \\
\hline 5 & 18 & - & - & 89 & $0.091 \pm 0.1143$ & $0.10-0.60$ \\
\hline 6 & 169 & $0.052 \pm 0.1257$ & $0.01-1.26$ & - & - & - \\
\hline
\end{tabular}

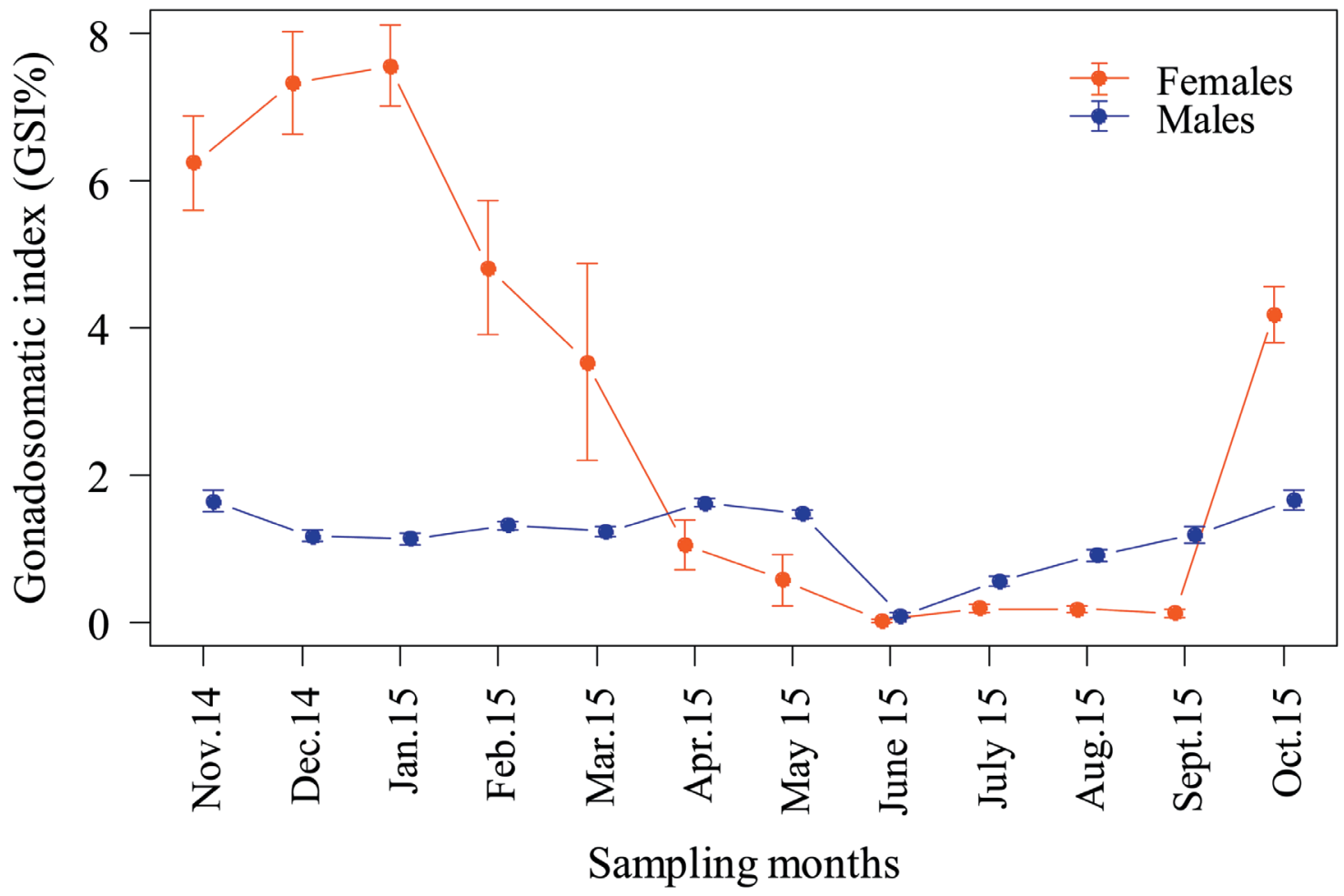

Fig. 5. Monthly variations in the gonadosomatic index (GSI\%) values of the female $(N=2207)$ and male $(N=4058)$ Carcinus aestuarii in Kirdeniz Lagoon. Vertical bars denote the 95\% confidence intervals

ing females (stage 6) were mainly recorded in May 2015. No immature female (stage 0) was observed in between November 2014 and May 2015. They were first captured in June 2015 in great quantities $(89 \%)$ and continued to predominate the samples until November 2015 (Fig. 4A).

The monthly distributions of maturity stages of male green crabs were somewhat different from those of the females. Mature males (stage
4) were observed throughout the study; however, they were more abundant in the samples from February to May 2015 with a clear peak $(59.8 \%)$ in April 2015 (Fig. 4B). After May 2015, the proportions of mature males in the samples were low, but there was an increase in October 2015. Resting males (stage 5) were quite rare in the samples and the highest proportion (6.3\%) was recorded in November 2014. No resting male crab was caught in September or October 2015. 


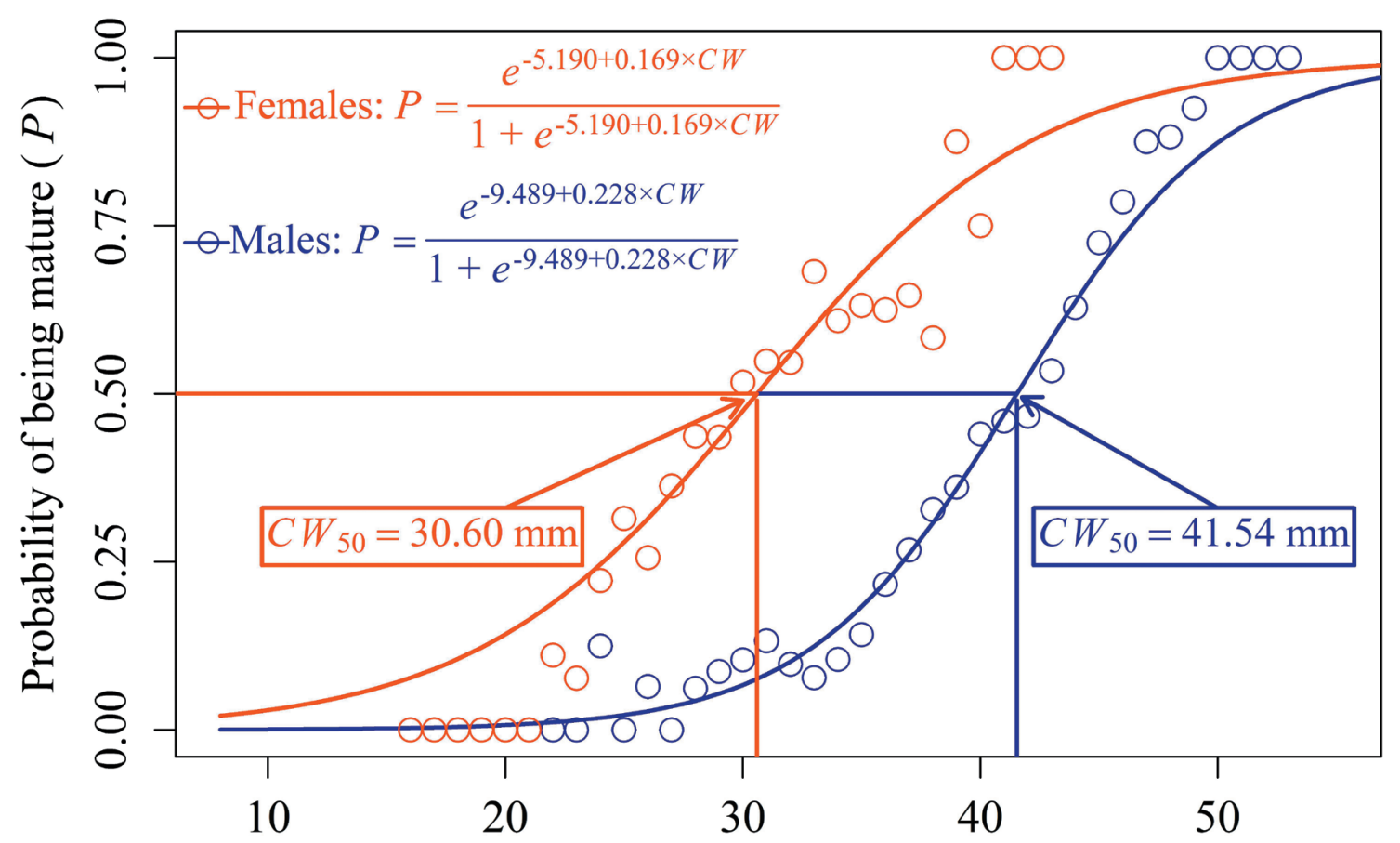

Carapace width $(\mathrm{mm})$

Fig. 6. The relationships between state of maturity and carapace width $(\mathrm{CW})$ for the female $(N=928)$ and male $(N=1087)$ Carcinus aestuarii in Kirdeniz Lagoon

As in the case of females, the samples from November 2014 to May 2015 did not contain any immature males. They, too, appeared first in June 2015 in large numbers and they were also predominant in the samples taken in July 2015. However, unlike females, the predominance of immature males ended as early as in August 2015 (Fig. 4B).

Variations in weights of green crab gonads according to maturity stages are presented for each sex in Table 5. Naturally, the gonads in both sexes expanded and grew heavier until maturity stage 5 , after which they decreased in size and weight. Female crabs had on average heavier gonads than the males at all maturity stages (Table 5). The heaviest gonad recorded was $3.31 \mathrm{~g}$ and it was dissected from a female crab at maturity stage 4 , with a $C W$ of $42 \mathrm{~mm}$ and sampled in November 2014. The heaviest male gonad was noted from a specimen again at a maturity stage 4 and with a $C W$ of $37 \mathrm{~mm}$ in October 2015.
The monthly variations in the GSI values of male and female green crabs in Kirdeniz Lagoon are shown in Fig. 5. Monthly mean GSI values of female and male crabs were in the range $0.02-7.56 \%$ and $0.09-1.66 \%$, respectively. The maximum observed individual GSI value was $25.15 \%$ from a female specimen with a $33 \mathrm{~mm}$ of $C W$ sampled in December 2014. The highest calculated GSI value for males was $11.20 \%$ based on a specimen caught in November 2014, with a $C W$ of $34 \mathrm{~mm}$. The mean GSI values of females increased from November 2014 to January 2015 and thereafter fell rather steeply. The minimum mean value was noted in June 2015. The female GSI values were very low in the following months until October 2015 when the mean value rose promptly (Fig. 5). Even though the monthly progression of the mean GSI values of males did not exactly match that of females, both sexes had high values in November and December 2014, and in October 2015. The minimum mean GSI value for males was likewise observed in June 2015. Starting from July 2015, 
the male GSI values started to increase gradually and reached a peak value in October 2015 (Fig. 5). The logistic models fit via the generalized linear model to the binomial maturity data of female and male crabs with the observed proportions of maturity are presented in Fig. 6. Only the data from the main reproductive period, as shown in Fig 5, including November and December 2014 and January and October 2015 were considered. Based on the respective regression coefficients of $a$ and $b$, the median size at first maturity $\left(C W_{50}\right)$ for females' green crabs was estimated as $30.6 \mathrm{~mm}$ and for males as $41.5 \mathrm{~mm}$. According to these estimates, females reach sexual maturity at a smaller size, at a $C W$ approximately $11 \mathrm{~mm}$ narrower, than males.

\section{Fecundity}

In total, 28 female green crabs at maturity stage 4 ( $C W$ range: $25-40 \mathrm{~mm}$ ), and 9 ovigerous females at maturity stage 5 ( $C W$ range: $28-37$ $\mathrm{mm}$ ) were used for estimation of potential and realized fecundity, respectively. The estimated average potential fecundity was 63565 with a standard deviation of 36519 . The minimum number of oocytes was 16589 and it was estimated from gonads of a female having a $29 \mathrm{~mm} \mathrm{CW}$, and the maximum number was 163281 which was based on a female with a $C W$ of $40 \mathrm{~mm}$. The mean number of fertilized eggs, as an estimator of average realized fecundity, was 42810 and its standard deviation was 33310. The minimum and maximum counts of fertilized eggs were 7773 and 103567. Even though the estimated mean number of oocytes (63565) was found to be higher than the estimated mean number of fertilized eggs (42810), the difference between these two means was not statistically significant (t-test). The variances associated with these means were also homogenous (F-test).

\section{DISCUSSION}

The sex ratio of the Mediterranean green crab in Kirdeniz Lagoon in the Gediz Delta was male biased throughout the one-year study period from November 2014 to October 2015 with the exception of only one month, September 2015. The preponderance of males became more marked after January 2016, and peaked in April 2016. From June 2016, the number of females in the samples started to increase (Fig. 2). A clear predominance of males was also observed in four other studies. FUROTA et al. (1999) in Tokyo Bay in Japan, where the green crab is an exotic invasive species, LUMARE et al. (2009) in Acquatina Lagoon in Italy and JOUILI et al. (2016) in Elbibane Lagoon in Tunisia found more males than females in every monthly sample they collected. In a shorter survey of eight months in Varano Lagoon in Italy, CILENTI et al. (2014) also caught mostly male crabs. On the other hand, female biased sex ratios along a whole study period were reported by CRIVELLI (1982) in Tampan Lagoon in southern France and by BAKLOUTI et al. (2013a) in the Gulf of Gabes in Tunisia. Apart from the abovementioned work, no continuous strong predominance of either sex, but monthly variations in the sex ratio were documented by four different investigations as well; MORI et al. (1990) in San Teodoro Lagoon in Sardinia, Italy, CAN et al. (2004) in Çakalburnu Lagoon in Turkey, ÖZBEK et al. (2012) in Homa Lagoon in Turkey and GLAMUZINA et al. (2017) in Parila Lagoon in Croatia. CAN et al. (2004) and ÖZBEK et al. (2012) observed higher proportions of females in the samples taken in August-November, and August and October-December. GLAMUZINA et al. (2017) and MORI et al. (1990) found mostly female crabs in December-February and February, respectively. The prevalence of males outside these time periods in the abovementioned lagoons is most likely related to the migratory behavior of mature female crabs, particularly ovigerous individuals, from estuaries to the sea. This periodic migration of female green crabs, which was remarked on by CRIVELLI (1982), MORI et al. (1990), ÖZBEK et al. (2012) and MATOZZO et al. (2013), elucidates the temporal variations in the observed sex ratios in Kurdeniz Lagoon. The mated mature females started to leave Kurdeniz Lagoon after January while males remained there as an indication of their territorial nature (Fig. 2). The increase of females in the samples from June and after was due to the recruitment of young crabs into the lagoon (Fig. 2 and Fig. 
3). The migratory behavior also explains the very low number of ovigerous females and why they were encountered only in December and January in the present study.

The observed maximum and average size $(\mathrm{CW})$ and weight of both female and male green crabs in Kirdeniz Lagoon (Table 1) were consistently lower than those stated in all other studies in the Mediterranean and Black Sea (e.g. LUMARE et al., 2009; ÖZBEK et al., 2012; AYDIN, 2013, BAKLOUTI et al., 2013a; JOUILI et al., 2016; GLAMUZINA et al., 2017) excepting only one, CAN et al. (2004), where recorded $C W$ and $W$ for females and males were in the range $6-41 \mathrm{~mm}$, $0.3-22 \mathrm{~g}$ and 5-52 mm, 0.1-44 g, respectively. So, the green crab populations in Kurdeniz and Çakalburnu Lagoons seem to consist of relatively small sized individuals compared to other studied populations in the Mediterranean. This may be attributed to the dissimilar ecological conditions in different lagoons including available food and predators, as well as the differences in sampling methodologies, and needs to be further investigated.

The observations made in the present study that male green crabs were, on average, bigger and heavier than females in every monthly sample, are consistent with the findings of CRIVELLI (1982), MORI et al. (1990), CAN et al. (2004), LUMARE et al. (2009) ÖZBEK et al. (2012), BAKLOUTI et al. (2013a), MATOZZO et al. (2013), JOUILI et al. (2016) and GLAMUZINA et al. (2017) in various places in the Mediterranean Sea. Interestingly, the only contradictory study to the above mentioned work is that of AYDIN (2013), where the author revealed that the largest green crab sampled in the eastern Black Sea was a female specimen having a $92 \mathrm{~mm} \mathrm{CW}$ and $172 \mathrm{~g} \mathrm{~W}$. It should be also noted that the largest male gathered in the Black Sea had a $C W$ of $86 \mathrm{~mm}$ and a $W$ of $164 \mathrm{~g}$, and it was considerably bigger than any maximum size measured for a male crab in all surveys in the Mediterranean. However, the discrepancy regarding the presence of larger females than males may be resolved in the future with new investigations on this species in the eastern Black Sea.

There were only three other investigations providing the necessary linear regression coef- ficients to enable the conversion of the two size variables $C W$ and $C L$ for each sex separately (MORI et al., 1990; KOÇAK et al., 2011; AYDIN, 2013). The estimated values of coefficients, particularly the slopes of regression equations (i.e. rate of change in one size variable as the other one varies), in the present study are very close to those reported by MORI et al. (1990), KOÇAK et al. (2011) and AYDIN (2013).

The estimated $b$ values of the $W-C W$ relationship for male and female green crabs in Kurdeniz Lagoon showed that both sexes followed a slightly negative allometric growth pattern (i.e. $b<3$ ) (Table 2). Similarly, MORI et al. (1990), CAN et al. (2007), KOÇAK et al. (2011), JOUILI et al. (2016) and GLAMUZINA et al. (2017) recorded negative allometric growth for both male and female green crabs collected from the lagoons of San Teodoro, Çakalburnu, Homa, Elbibane and Parila, respectively. On the other hand, CRIVELLI (1982) in Tampan Lagoon and BAKLOUTI-ZOUARI (2010) in the Gulf of Gabes found that females exhibited an isometric growth pattern whiles males showed a positive allometric growth (i.e. $b>3$ ). Regardless of the growth pattern, in all the studies mentioned above including the present work, the recounted $b$ estimates for males were higher than those for females. That is, for a similar $C W$, males were heavier than females and as they grew, they became bulkier, which is consistent with the size related sexual dimorphism previously discussed. The observations made by AYDIN (2013) on green crabs in the eastern Black Sea, however, diverged from this general trend. The estimated $b$ values of $W-C W$ relationship in the Black Sea were 3.078 and 3.080 for females and males, respectively and they were statistically indifferent from each other. Considering the previously mentioned larger maximum sizes and the positive allometric growth, the ecological conditions in the Black Sea appear to be quite favorable for the growth of green crabs.

The present study is the first attempt to estimate the von Bertalanffy growth parameters, and total mortality rates for a green crab population in the eastern Mediterranean (Table 3). There are only two other studies that provide growth parameter estimates for green crabs; one 
in Elbibane Lagoon in the Gulf of Gabes (JOUILI et al., 2016) and the other in Parila Lagoon in the Adriatic Sea (GLAMUZINA et al., 2017). JOUILI et al. (2016) also applied the ELEFAN routine, however, it was incorporated in another software namely FISAT II (GAYANILO et al., 2005). The estimated parameters were based on $C L$ measurements instead of $C W$ and the values of $C L_{\infty}$ and $K$ were $49.35 \mathrm{~mm}, 0.87$ year $^{-1}$ for females and $55.70 \mathrm{~mm}, 0.75$ year $^{-1}$ for males (JOUILI et al., 2016). A comparison can be made between the asymptotic sizes obtained in the present study and those of JOUILI et al. (2016) by converting this study's $C W_{\infty}$ estimates 49 and $54 \mathrm{~mm}$ for females and males, respectively, to corresponding $C L_{\infty}$ values of 42 and $47 \mathrm{~mm}$ by using the linear regression coefficients previously calculated. The asymptotic sizes of both male and female crabs in Elbibane Lagoon are bigger than in the present findings. This appears to corroborate the earlier remark that the green crab population in Kirdeniz Lagoon seems to be formed by relatively small sized individuals compared to other studied populations in the Mediterranean. This assertion is also supported by the growth parameters estimated by GLAMUZINA et al. (2017) where $C W_{\infty}$ and $K$ were $50.49 \mathrm{~mm}$, 0.795 year $^{-1}$ for females and $71.29 \mathrm{~mm}, 0.678$ year $^{-1}$ for males. In all three studies including the present one, males had a larger asymptotic size than females which is as expected given the sexual dimorphism displayed by this species.

The median size at first maturity $\left(C W_{50}\right)$, i.e. a $C W$ value at which $50 \%$ of all crabs are sexually mature, is an important parameter in studies on the reproductive biology of decapods. In addition to enabling the demarcation of the parental part of a population, it also serves as a crucial threshold for a sustainable exploitation of any population. Therefore, the task of determining the size at first maturity of green crabs was undertaken by several workers in various regions in the Mediterranean Sea. Early works focused mostly on ovigerous females and maturity of male crabs was rarely studied. Often, the observed size range of ovigerous females was evaluated and either mean size or size of the smallest ovigerous female was reported as the onset of the sexual maturity. VEILLET (1945) (as cited in MORI et al., 1990) in Thau Lagoon in Séte, France, CRIVELLI (1982) in Tampan Lagoon, LUMARE et al. (2009) in Acquatina Lagoon and JOUILI et al. (2016) in Elbibane Lagoon, all noted the smallest $\mathrm{CW}$ measurements of ovigerous females; 21, 28, 23 and $31 \mathrm{~mm}$ respectively, as the size when female green crabs reached puberty. DÉMEUSY (1958) (as cited in MORI et al., 1990) in Séte, France preferred to state the mean $C W$ of ovigerous females, $25 \mathrm{~mm}$ (range: 20-29 mm), as the sexual maturity size. MORI et al. (1990) was the first study providing an estimate of sexual maturity size for male green crabs. However, their method of estimation was based on the relationship of two morphological variables, namely $C W$ and chela width. The authors log transformed the $C W$ and chela width measurements of male crabs and plotted them against each other producing a pattern consisting of two straight lines, one describing the relative growth of juveniles, and the other one describing the relative growth of adults, and they defined the intersection point as the size at sexual maturity. For the determination of sexual maturity size of females, MORI et al. (1990) employed a graphical method based on a probability paper on which cumulative percentages of ovigerous females were shown for each $C W$ class of $1 \mathrm{~mm}$. Then $C W_{50}$ was simply the size class where $50 \%$ of the females were ovigerous. The estimated sexual maturity size for females was $29.1 \mathrm{~mm} \mathrm{CW}$ and for males $34.1 \mathrm{~mm} \mathrm{CW}$ in San Teodoro Lagoon (MORI et al., 1990). Two more recent investigations on the reproductive biology of green crabs, ÖZBEK et al. (2012) and GLAMUZINA et al. (2017) were also concentrated on solely ovigerous females. Both studies used a logistic equation relating the percentage of ovigerous females to the $C W$ classes and found the corresponding sizes containing $50 \%$ ovigerous specimens, and they were $26.8 \mathrm{~mm}$ for Homa Lagoon and $29.6 \mathrm{~mm}$ for Parila Lagoon (ÖZBEK et al., 2012; GLAMUZINA et al., 2017). One final work was that of BAKLOUTI et al. (2013a), who examined gonads of both sexes and, by employing a logistic equation, estimated the median sizes at puberty to be $34.6 \mathrm{~mm} \mathrm{CW}$ for 
females and $43.9 \mathrm{~mm} \mathrm{CW}$ for males in the Gulf of Gabes. The present study was similarly based on maturity stages of gonads of both sexes of green crabs sampled in Kirdeniz Lagoon. Thus, the median sizes at first maturity estimated here $30.6 \mathrm{~mm} \mathrm{CW}$ for females and $41.5 \mathrm{~mm} \mathrm{CW}$ for males are strictly comparable only with the findings of BAKLOUTI et al. (2013a). However, when the size of the smallest ovigerous female $(27 \mathrm{~mm} \mathrm{CW}$ ) encountered in the present study was considered, the variations in the size at first maturity for green crabs in the different regions of the Mediterranean Sea seem to be negligible. It should also be noted that all three investigations (MORI et al., 1990; BAKLOUTI et al., 2013a and the present study) examining sexual maturity of both sexes, irrespective of the methodology used, revealed that female crabs matured at a smaller size than males, which is in accordance with the size related sexual dimorphism in green crabs.

From the temporal variations in maturity stages of mainly female gonads (Fig. 4A) and GSI values (Fig. 5), and the presence of ovigerous specimens, it can be deduced that the breeding season of the Mediterranean green crab in Kirdeniz Lagoon clearly spreads from mid fall to early spring (October-March) with a peak in winter (December-February). As a consequence, the recruitment of juveniles to the lagoon takes place predominantly in summer (June-August) (Fig. 3). The breeding period observed in the present study is, in general, in agreement with the breeding seasons reported by other surveys carried out in different regions of the Mediterranean Sea e.g. in Thau Lagoon and Séte in the Gulf of Lion (VEILLET, 1945; DÉMEUSY, 1958, as both cited in MORI et al., 1990), San Teodoro Lagoon in the Tyrrhenian Sea (MORI et al., 1990), Homa Lagoon in the Aegean Sea (ÖZBEK et al., 2012), the Gulf of Gabes (BAKLOUTI et al., 2013a), and Parila Lagoon in the Adriatic Sea (GLAMUZINA et al., 2017). Naturally, some small differences between the regions were also recognized. For example, MORI et al. (1990), while also identifying the peak time of breeding as February, declared that breeding season could extend in San Teodoro Lagoon from November to early
May. Similarly, based on the maximum average female GSI value calculated (7.57\%), BAKLOUTI et al. (2013a) stated the major breeding peak was in October in the Gulf of Gabes; whereas in the present study, the highest average female GSI value $(7.56 \%)$ was seen in January. Such variations could be related to the differing regional and temporal ecological conditions since all these surveys were conducted in different years.

The findings of the present work also reveal that the green crabs in Kirdeniz Lagoon have only one single breeding period and consequently produce only one brood per year. MORI et al. (1990), ÖZBEK et al. (2012), BAKLOUTI et al. (2013a) and GLAMUZINA et al. (2017), likewise, noted one single spawning period per year in the regions they worked. However, on observing juvenile green crabs having $5 \mathrm{~mm} C W$ in October, CRIVELLI (1982) suggested the presence of two separate breeding cycles in one year in Tampan Lagoon; first a relatively more intensive one in January-February and a second one in September. This hypothesis of two spawning periods per year was previously proposed by AMANIEU et al. (1978) (as cited in CRIVELLI, 1982) based on examinations of population age structure of green crabs. A similar reproductive trait of biannual spawning periods was also reported by LYONS et al. (2012) for another congener, namely C. maenas from the south west coast of Ireland. More than one spawning period is considered to be very unlikely for the Kurdeniz Lagoon green crab population because, in addition to all observations on the annual progression of gonad maturation stages and GSI values of female crabs and recruitment of juveniles, inspection of the gonads of the ovigerous females sampled during the present study did not present any sign of vitellogenesis.

The average fecundity estimates $( \pm$ their standard deviations if available) recorded for female green crabs by the previous investigations in the Mediterranean were $71101 \pm 31543$ eggs in Acquatina Lagoon (LUMARE et al., 2009), 42201 eggs in Homa Lagoon (ÖZBEK et al., 2012), $30750 \pm 11176$ eggs in the Gulf of Gabes (BAKLOUTI et al., 2013a), 45468 in Elbibane Lagoon (JOUILI et al., 2016) and 61017 eggs in Parila 
Lagoon (GLAMUZINA et al., 2017). All these mentioned fecundity analyses were directed only at the counting of fertilized eggs carried by ovigerous females, which is referred to as realized fecundity here. In the present study in addition to the realized fecundity, another measure of fecundity which is based on the estimation of number of oocytes contained in female gonads at maturity stage 4, namely potential fecundity was also attempted. The average potential fecundity estimate was $63565 \pm 36519$ oocytes per female green crab in Kirdeniz Lagoon. On the other hand, the average realized fecundity was found to be $42810 \pm 33310$ eggs per female. Even though a reduction between these two different measures of fecundity, i.e. a decrease in actual reproductive production during the progress of oocytes to fertilized eggs, is anticipated due to several ecological factors such as success of fertilization, loss of eggs, parasites, lack of growth etc, the observed difference between the two separate average fecundity estimates was not statistically significant, furthermore the associated standard deviations were also homogenous. Therefore, the present results were fairly comparable to the aforementioned average fecundity estimates provided by LUMARE et al. (2009), ÖZBEK et al. (2012), BAKLOUTI et al. (2013a), JOUILI et al. (2016) and GLAMUZINA et al. (2017).

The present work has provided new information on the reproductive biology and population dynamics of the Mediterranean green crab in the eastern Aegean Sea, and may hopefully serve as a reference for future research. Although the species itself may be of minor commercial importance, its prime position within the intermediate trophic levels in the coastal ecosystem, like many other small brachyurans, means that a better understanding of its population dynamics is required.

\section{ACKNOWLEDGEMENTS}

The authors would like to thank Ege University for supporting this study by funds from Ege University Scientific Research Projects Coordination Unit (Project No: 2014-SUF-016).

\section{REFERENCES}

ANDERSON, O.N. \& R.M. NEUMANN. 1996. Length, weight, and associated structural indices. In: B.R. Murphy \& W.D. Willis (Editors), Fisheries techniques, $2^{\text {nd }}$ edition. American Fisheries Society, Maryland, pp. 447-482.

AYDIN, M. 2013. Length-weight relationship and reproductive features of the Mediterranean green crab, Carcinus aestuarii Nardo, 1847 (Decapoda: Brachyura) in the eastern Black Sea, Turkey. Pak. J. Zool., 45: 1615-1622.

BAKLOUTI, S., A. DERBALI, K. DHIEB \& O. JARBOUI. 2013a. Reproductive biology of the Mediterranean green crab, Carcinus aestuarii Nardo, 1847 (Crustacea: Portunidae), in the Gulf of Gabes (Tunisia, Central Mediterranean). Cah. Biol. Mar., 54: 411-417.

BAKLOUTI, S., A. DERBALI, K. DHIEB, W. KAMMOUN \& O. JARBOUI. 2013b. Proximate composition and its seasonality of the Mediterranean green crab: Carcinus aestuarii Nardo, 1847 (Brachyura, Portunidae), in southern
Tunisian waters (Central Mediterranean). J. Mar. Biol., 2013: 1-6.

BAKLOUTI-ZOUARI, S. 2010. Contribution à l'etude ecobiologique et biochimique du crabe Carcinus aestuarii dans la region nord de Sfax. M.Sc. Thesis, University of Sfax, Faculty of Science, Tunisia, $90 \mathrm{pp}$.

BEVERTON, R.J.H. \& S.J. HOLT. 1956. A review of methods for estimating mortality rates in fish populations, with special reference to sources of bias in catch sampling. Rapp. Cons. Int. Explor. Mer, 140: 67-83.

BEVERTON, R.J.H. \& S.J. HOLT. 1957. On the dynamics of exploited fish populations. Fisheries Investigations, Series 2, London, 533 pp.

CAN, E., E.M. TIRAŞIN \& B. CIHANGIR. 2004. An investigation of the crab Carcinus aestuarii, (Nardo, 1847) in the Çakalburnu Lagoon. Turk. J. Aquat. Life, 2: 77-84.

CAN, E., E.M. TIRAŞIN, B. CIHANGIR \& U. YILMAZ. 2007. Weight-carapace width relationship of 
the Mediterranean green crab (Carcinus aestuarii, Nardo 1847) in Cakalburnu Lagoon, İzmir Bay. Rapp. Com. int. Mer Médit., 38: p. 443.

CHEN, R.B., S. WATANABE \& M. YOKOTA. 2004. Feeding habits of an exotic species, the Mediterranean green crab Carcinus aestuarii, in Tokyo Bay. Fish. Sci., 70: 430-435.

CILENTI, L., G. D'ERRICO, T. SCIROCCO, C. MANZO \& A. FABBROCINI. 2014. Spatial variability in the population structure of the Carcinus aestuarii in Varano lagoon. Trans. Waters Bull., 8: 24-31.

CRIVELLI, A.J. 1982. Biology of three Malacostraca (Decapoda) in a Mediterranean lagoon with particular emphasis on the effect of rapid environmental changes on the activity (catchability) of the species. Est. Coast. Shelf Sci., 15: 591-604.

DELI, T., K. SAID \& N. CHATTI. 2015. Genetic differentiation among populations of the green crab Carcinus aestuarii (Nardo, 1847) (Brachyura, Carcinidae) from the eastern and western Mediterranean coast of Tunisia. Acta Zool. Bulg., 67: 327-335.

FISCHER, W., M.L. BAUCHOT \& M. SCHNEIDER. 1987. Fiches FAO d'identification des espèces pour les besoins de la pêche. Méditerranée et mer Noire. Zone de pêche 37, Vol. I. Végétaux et invertébrés, FAO, Rome, 760 pp.

FUROTA, T., S. WATANABE, T. WATANABE, S. AKIYAMA \& K. KINOSHITA. 1999. Life history of the Mediterranean green crab, Carcinus aestuarii Nardo, in Tokyo Bay, Japan. Crustac. Res., 28: 5-15.

GAYANILO, F.C., P. SPARRE \& D. PAULY. 2005. FAOICLARM Stock assessment tools II (FiSAT). Version 1.2.2. FAO, Rome, Italy.

GLAMUZINA, L., A. CONIDES, G. MANCINELLI, T. DOBROSLAVIĆ, V. BARTULOVIĆ, S. MATIĆSKOKO \& B. GLAMUZINA. 2017. Population dynamics and reproduction of Mediterranean green crab Carcinus aestuarii in Parila Lagoon (Neretva Estuary, Adriatic Sea, Croatia) as fishery management tools. Mar. Coast. Fish., 9: 260-270.

HOGGARTH, D.D., S. ABEYASEKERA, R.I. ARTHUR, J.R. BEDDINGTON, R.W. BURN, A.S. HALLS, G.P. KIRKWOOD, M. MCALLISTER, P. MEDLEY, C.C. MEES, G.B. PARKES, G.M. PILLING,
R.C. WAKEFORD \& R.L. WELCOMME. 2006. Stock assessment for fishery management: A framework guide to the stock assessment tools of the fisheries management and science programme. FAO Fisheries Technical Paper, No. 487, FAO, Rome, 261 pp.

HOLTHUIS, L.B. 1961. Report on a collection of Crustacea Decapoda and Stomatopoda from Turkey and the Balkans. Zool. Verh., 47: $1-67$.

HOSMER, D.W. \& S. LEMESHOW. 2000. Applied logistic regression. 2nd edition. Wiley Series in Probability and Statistics. John Wiley \& Sons, New York, 375 pp.

INGLE, R. 1997. Crayfishes, Lobsters and Crabs of Europe. An Illustrated Guide to Common and Traded Species. Chapman \& Hall, London, $281 \mathrm{pp}$.

JOUILI, S., M. ARCULEO, L. MANSOUR \& L. RABAOUI. 2016. Biological characteristics of three Brachyuran crab species in the Lagoon of Elbibane, South-Eastern Tunisia. Cah. Biol. Mar., 57: 217-226.

KOCATAŞ, A. \& T. KATAĞAN. 2003. The decapod crustacean fauna of the Turkish seas. Zool. Middle East, 29: 63-74.

KOÇAK, C., D. ACARLI, T. KATAĞAN \& M. ÖZBEK. 2011. Morphometric characters of the Mediterranean green crab (Carcinus aestuarii Nardo, 1847) (Decapoda, Brachyura), in Homa Lagoon, Turkey. Turk. J. Zool., 35: 551-557.

LEIGNEL V., J.H. STILLMAN, S. BARINGOU, R. THABET \& I. METAIS. 2014. Overview on the European green crab Carcinus spp. (Portunidae, Decapoda), one of the most famous marine invaders and ecotoxicological models. Environ. Sci. Pollut. Res., 21: 9129-9144.

LUMARE, L., D. LUMARE, M. FLORIO, T. SCIROCCO \& F. LUMARE. 2009. I crostacei decapodi del lago di Acquatina: struttura delle popolazioni e ciclo riproduttivo. Thalassia Salent., 31 (suppl.): 83-102.

LYONS, L.J., R.M. O'RIORDAN, T.F. CROSS \& S.C. CULLOTY. 2012. Reproductive biology of the shore crab Carcinus maenas (Decapoda, Portunidae): a macroscopic and histological view. Invertebr. Reprod. Dev., 56: 144-156.

MATOZZO, V., A. BOSCOLO \& M.G. MARIN. 2013. 
Seasonal and gender-related differences in morphometric features and cellular and biochemical parameters of Carcinus aestuarii from the Lagoon of Venice. Mar. Environ. Res., 89: 21-28.

MORI, M., R. MANCONI \& G. FANCIULLI. 1990. Notes on the reproductive biology of Carcinus aestuarii Nardo (Crustacea, Decapoda) from the Lagoon of San Teodoro (Island of Sardinia, Italy). Riv. Idrobiol., 29: 763-774. MURUA, H., G. KRAUS, F. SABORIDO-REY, P.R. WITTHAMES, A. THORSEN \& S. JUNQUERA. 2003. Procedures to estimate fecundity of marine fish species from field samples in relation to reproductive strategy. J. Northwest Atl. Fish. Sci., 33: 33-54.

ÖZBEK, M., C. KOÇAK \& D. ACARLI. 2012. Reproductive biology of the Mediterranean green crab Carcinus aestuarii Nardo, 1847 (Crustacea, Brachyura, Portunidae) in Homa Lagoon, Aegean Sea, Turkey. Oceanol. Hydrobiol. Stud., 41: 77-80.

PAULY, D. \& N. DAVID. 1981. ELEFAN I, a BASIC program for the objective extraction of growth parameters from length-frequency data. Meeresforsch., 28: 205-211.

PAULY, D. \& J.L. MUNRO. 1984. Once more on the comparison of growth in fish and invertebrates. Fishbyte, 2: 21.

R CORE TEAM. 2017. R: A language and environment for statistical computing. R Foundation for Statistical Computing, Version 3.3.3. Vienna, Austria.

RAGIONIERI, L. \& C.D. SCHUBART. 2013. Population genetics, gene flow, and biogeographical boundaries of Carcinus aestuarii (Crustacea: Brachyura: Carcinidae) along the European Mediterranean coast. Biol. J. Linn. Soc., 109: 771-790.

SALMAN, A. \& M. AKALIN. 2019. Histological description of gonadal development of Carcinus aestuarii (Decapoda:Portunidae). Cah. Biol. Mar., 60: 477-488.

SNEDECOR, G.W. \& W.G. COCHRAN. 1989. Statistical methods. 8th edition. Iowa State Univ. Press, Ames, Iowa, 503 pp.

SPARRE, P. \& S.C. VENEMA. 1998. Introduction to tropical fish stock assessment. FAO Fisheries Technical Papers. No. 306/1, Rev. 2 (Part 1) FAO, Rome, 407 pp.

ŠTEVČIĆ, Z. \& B. GALIL. 1993. Checklist of the Mediterranean brachyuran crabs. Acta Adriat., 34: 5-76. 


\title{
Dinamika populacije mediteranskog zelenog raka Carcinus aestuarii Nardo, 1847. (Crustacea: Portunidae) u delti rijeke Gediz (zaljev Izmir, Istočno Egejsko more)
}

\author{
Eyüp Mümtaz TIRAŞIN*, M. SALMAN, Meryem AKALIN i Okan ÖZAYDIN \\ *Kontakt e-pošta: mumtaz.tirasin@deu.edu.tr
}

\begin{abstract}
SAŽETAK
Sakupljeno je 6265 jedinki mediteranskog zelenog raka Carcinus aestuarii iz delte rijeke Gediz $\mathrm{u}$ istočnom Egejskom moru (Turska) tijekom 24 ispitivanja uzoraka u intervalima od 15 dana od studenog 2014. do listopada 2015. godine.

Ukupni omjer mužjaka i ženki iznosio je 1:8. Mužjaci su bili prevladavajući u svim istraživanjima uzoraka, osim u rujnu 2015. Rasponi ukupne mase (W) i širine glavopršnjaka (CW) za sve rakove iznosili su 0,19-45,74 g i 8-53 mm. Mužjaci su bili u prosjeku veći i teži od ženki. Odnosi ukupne težine i širine glavopršnjaka su iznosili $\mathrm{W}=0,0004 \times \mathrm{CW}^{2,88}$ za ženke, a $\mathrm{W}=0,0003 \times \mathrm{CW}^{2,96} \mathrm{za}$ mužjake.

Procijenjeni parametri rasta ženki prema von Bertalanffy-jevoj jednadžbi iznosili su: $\mathrm{CW}_{\infty}$ gdje $\mathrm{je}=49 \mathrm{~mm}, \mathrm{~K}=0,82$ godina $^{-1} \mathrm{i}_{0}=-0,9$ godina, a za mužjake $\mathrm{CW} \infty=54 \mathrm{~mm}, \mathrm{~K}=0,92$ godina $^{-1} \mathrm{i}$ $\mathrm{t}_{0}=-0,96$ godina. Ukupna smrtnost ženki iznosila je 2,25 godina $^{-1}$ dok je za mužjake iznosila 2,27 godina ${ }^{1}$.

Razdoblje razmnožavanja seže od sredine jeseni do ranog proljeća, te dostiže vrhunac zimi.

Novačenje mlađi u laguni se pretežito odvija u ljetnom periodu. Srednja veličina jedinki pri prvoj spolnoj zrelosti bila je 30,6 mm za žene i 41,5 mm za mužjake. Prosječna potencijalna procjena plodnosti iznosila je $63565 \pm 36519$ oocita po ženki rakova, dok je prosječna ostvarena plodnost iznosila $42810 \pm 33310$ jajašaca.
\end{abstract}

Ključne riječi: Mediteranski zeleni rak, Carcinus aestuarii, rast, smrtnost, razmnožavanje, veličina jedinki pri prvoj zrelosti 
